\title{
RECONSTITUTION OF A LOST ORIGINAL VIA \\ EARLIEST DISTRIBUTION: \\ DIE SÄCHSISCHE WELTCHRONIK
}

(A-RECENSION)

The Saxon Universal Chronicle (Die Sächsische Weltchronik $=S W$ ), an aristocratic chronicle probably composed c. 1235 , is generally regarded as one of the most impressive medieval prose compendia and has traditionally been ascribed to Eike von Repgow (Reppichau near Aken on the Elbe), who is known to have authored the Sachsenspiegel (c. 1220-30) from which the Swabian Lantrechtbuoch or so-called "Schwabenspiegel" (c. 1270) derives. ${ }^{1} S W$ is highly significant as a literary monument, for it is the first vernacular prose chronicle of the "universal" genre and thus forms a distinct break with the broad stream of rhymed chronicles of the 12th century. Among medieval encyclopedic universal chronicles, it is virtually unique in its amplitude, incidental coherence, implementation of sources, episodic characterization, and innovative fusion of the clerical and the aristocratic: it is an ideal source for cognizance of the relevant mental stances and intellectual attitudes of its time. Due to repeated and comparatively frequent redaction over several centuries, it is an invaluable testimonial of the emergence of shifting modes of historical perception and judgment in the later Middle Ages. Finally, it is linguistically of considerable consequence, for its successive redactions frequently served as stylistic and syntactic models and thus played an important role in the evolution of vernacular prose, particularly, as we shall demonstrate, in Upper German-Bavarian. ${ }^{2}$ The $S W$ is therefore an excellent text for the observation of language change in literature.

In addition to the Regensburg Kaiserchronik (c. 1150), two primary sources for the $S W$ are the Latin Frutolf Chronicle, which extended through anno 1125 in the redaction by Ekkehard of Aura, and the Annales Palidenses from the cloister of Pöhlde. However, despite recent scholarship, it is still a contested matter whether or not and, if so, to what extent $S W$ 's author(s) or redactors employed the other sources, e.g. the Chronica Domni, Historia Scholastica, Acta St. Silvestri, Historia Francorum, Decretum Gratiani, and Stader Annals, listed by Ludwig Weiland, ${ }^{3}$ who first edited the $S W$ as the inaugural volume of the series, Deutsche Chroniken und andere Geschichtsbücher des Mittelalters, of the Monumenta.

Including fragments, some of which consist of but one leaf, there are thirty-four known manuscripts of the $S W$, ten of which were unknown to Weiland, who grouped the manuscripts into three recensions, the classification employed yet today: A = MSS 1-12, B = MSS 13-17, C = MSS 18-24. MSS A 1-8 conclude with sec. 366 (January, 1225), A 9 at sec. 369 (November, 1225), A 11-12 (and A 12a, a copy of A 12) at sec. 375 
(December 13, 1230), B 13-15 at sec. 379 (May, 1235), B 16 at sec. 398 (December 28, 1248), B 17, after a lacuna, at sec. 399 (to 1260), as do MSS C 18-24. C forms the most unified class in terms of both content and dialect; all its members are Low German or a mixture of Low and Middle German, while all members of B, with the exception of the Latin codex B 15, are distinctly and exclusively Low German. MSS 1-8 are Upper German (Alemannian) and Bavarian, and MSS A 9-12, with the exception of the Latin codex A 101, are Upper German or Middle German and/or Bavarian. Thus, while the A-recension MSS are predominantly Upper German-Bavarian, the manuscripts in recensions $B$ and $C$ are exclusively Middle German and/or Low German and fail to contain the so-called "Bavarian Continuations" found only in MSS A 2-7. MSS A 1-8 are clearly related stemmatically (see Table 2 ) and presumably, despite reservations on the part of some scholars, present the chronicle in its earliest form. We have therefore divided the A-recension into two subsets: A-1 and A-2 with the allocation of MSS $1-8$ to A-1 and MSS 9-12 to A-2 see Table 1.

It was almost exclusively on the basis of the sources educed by Weiland that Hermann Ballschmiede ${ }^{4}$ concluded that the A-recension alone derived from Eike, B from a cleric in the office of the archbishopric of Bremen, and C from a monk at the cloister of St. Michael (founded in 956 by Otto II) in Lüneburg. This interpretation is a fantasy spun from the tantalizing data assembled by Weiland: Ballschmiede committed the "classic" error of concluding that the provenience of sources employed is positive indication of the provenience of the text in which the sources are used. Karl August Eckhardt ${ }^{5}$, the legal historian, combined the results of Weiland's and Ballschmiede's investigations, made cursory readings of MSS 1, 10,10a, 11, and 12, and concluded that only A derived from Eike (c. 1230). He reordered the recensions as: B- (A plus interpolations from c. 1235) which originated in Bremen, C- (B plus interpolations from c. 1237-51) which originated in Lüneburg, and $C+(C$ plus the Hallberstadt extension from after 1248) which originated in Hallberstadt. Eckhardt's purely speculative conclusions have never merited general acceptance. In the most recent detailed study of the $S W$, Hubert Herkommer ${ }^{6}$ has conferred clarity upon traditions of the individual manuscripts, but contends that Eike was not the author of the $S W$ and that the C-recension represents the earliest version. For these latter conclusions he has been justly criticized, ${ }^{7}$ and currently the general concensus of scholars is that MSS A $1-8$ (here recension A-1) represent the earliest version of a chronicle authored by the Low German Eike. ${ }^{8}$

If, as we indicated in our brief survey of pertinent literature, tabular display of $S W$ manuscripts, and presentation of stemmatic filiation, ${ }^{9}$ recension A-1 represents the chronicle at its earliest remove from Eike's concept, then mystery immediately shrouds linguistic reconstitution of the original upon concomitant clarification of its earliest distribution. From 
the general Upper German provenience of recension A-1 alone, we infer that the earliest version achieved its initial prominence as a literary document in Upper-Germany, not in Eike's native Lower Saxony..$^{10}$ If we accept this inference, we are then plagued by the problems of detecting a proximate Low German original beneath an Upper German superstruction and of determining how and why the $S W$ apparently received initial acclaim in Southern, rather than Northern Germany. Given the historiographic, if not literary, merits of the chronicle qua chronicle, investigation of the latter problem may well cast light on a significant aspect of the status of Southern German historiography and the requisites of its chancery style in the late 13th and early 14th centuries. The most productive means of approaching the former problem are necessarily philological; while, for the latter, they are largely within the realm of the cultural historian: after establishment of the original scriptorial provenience of the A-1 texts in filiation, one must determine the relationship between those scriptoria and centers of learning in Northern Germany.

For the philological problem, we are restricted to a probe of variants for subsequent reconstruction of an underlying concept - in the one portion of the chronicle, with the exception of MS A- $-21,{ }^{11}$ common to all members of A-1; namely, $S W 78: 11-87: 3$, see Tables $1-3$ and Text ( $S W$ 78:11-25).

The following variants from SW 78:11-25 (Text) are dialectally distinctive for localization. pain (10:11 BDEGHI) with $b$ - > p- and ai for MHG $e i$ vs. pein $(\mathrm{C})$ and beyn $(\mathrm{F})$, where pain is distinctly Bavarian, pein (West)Alemannic, and beyn Middle German (Thuringian) after 1300. In the 13th century the Bavarian-Alemannic ailei distinction was still unclear, but by the 15 th century the ai-area was centralized south of a line from Regensburg to Stuttgart and east of a line from Stuttgart-RottweilLucerne. ${ }^{12}$ Note bain, brust, bug (10:11) in A with consistent retention of $b$-, as in (F) but ai for $e i$, an indication of Swabian provenience. ${ }^{13} \mathrm{Cf}$. realization of $e i$ in zwei (10:1): ailay (CDEG) with zwair (B) which shows contamination with the apocopated gen. in -e/or or -re/or, but note $e i$ in dreis(s)ig 10:1 C(D)EG). The 3. pl. pret. kommen (10:5 A), chomen $(\mathrm{BCD})$, kamen $(\mathrm{E})$ vs. quamen $(\mathrm{F})$, where $k$ - is distinctly Upper German and $q u$ - Middle German (Thuringian), though the alo distinction ( $a=$ Alemannic and $o=$ Bavarian) was no longer valid in the 15th century, as $k o m(e n)$ are attested from Alemannic in the 13th century, though not in the southwest (Basel-Lucerne), and $k$ - here (vs. ch-) is perhaps Swabian (Rottweil?). ${ }^{14}$ Evidence for divergent reflexes of MHG ou is indicated by houpt (10:11 A), the only text with ou vs. au (BDEFGH) and aw (CI). In the 15th century, $a u$ was distinctly Bavarian (east of the Lech) and East Middle German (Thuringian), while au/av are consistently absent from Alemannic sources from the 13th century onward. $a w$ in $\mathrm{C}$, otherwise thus far clearly Alemannic, presents an aberration. The 3. sg. pret. hatte $(10: 3 \mathrm{~F})$ is clearly Middle German. ${ }^{16}$ Retention of $i, u$ as monopthongs in 
the 15 th century was restricted to an area from Würzburg to Augsburg and east of the Lech, while the Swabian area west of the Lech exhibited remarkable resistence to dipthongization, and dipthongization did not penetrate the Upper Neckar-Danube area until the second half on the 16th century, while in the entire Bavarian sector, including Nuremberg, $e i$ for $i$ and $a u$ for $u$ reigned supreme, and Augsburg stands as a transitional zone. ${ }^{17}$ Diphthongization of $i$, e.g. $\operatorname{rich}(e)$ 10:8, is not indicated in AF, nor of $u$, e.g. bug 10:11, in AFG and note $b$ - in buch (G) vs. p- in pain (G); sul (AFG) vs. diphthongal forms in all other MSS: this portends linguistic affinity between $F$ and $G$ (or a copy of $F$ or a descendant of one of its intermediaries). Replacement of urliugten by criegten in $\mathrm{H}$ (10:2) is probably due to misreading: reinterpretation of $v$ as $c$ and $l$ as $i$. Note vrlegten in I and the fact that $\mathrm{H}$ is a copy of I: vrlegten is the proto-form for $\mathrm{HI}$. Moreover, of the MHG variants (urliugten, urlougten, urlugten, urlegten), the $e$-form (orlegen in Karlmeinet) is distinctly Middle German/Low German, while vrlaugten $(\mathrm{E})$ derives from urlougten with $a u$ for $o u$. Further evidence for a Middle or Low German source for $\mathrm{H}$ is provided by the olu-opposition (with or without umlaut) in kunig (ABCDEGI) vs. konig $(\mathrm{FH})$ in 10:10. Forms in $o / \ddot{o}$ are found north of the Main, while $u / \ddot{u}$ is the rule throughout Upper German and was the exclusive formant in the Thuringian-Saxon chancery until 1325; the same geographical distribution holds for guldin (10:11) vs. goldin, golden. ${ }^{18}$ Of particular note are reflexes of liuti-: lüten (ACDGHI), luten (EF), and lauten (B) in 9:23, where lauten must derive from a Bavarian area (Freising?) with coalescence of $i u$ and $u$ as $u$ and subsequent dipthongization, stemming from the southern edge of the Middle German area. ${ }^{19}$ Finally, $u$ vocalism in the pres. pl. of sollen (10:7 ABCDEG) is restricted to the region south of the Main, while $o$ vocalism $(F)$ is Middle German.

From this survey, however brief, we conclude that $\mathrm{F}$ is basically Middle German (Thuringian?) with Bavarian traits; HI, though Bavarian, evince Middle German/Low German influence; G, essentially Bavarian, and F are linguistically related; A is Low (West) Alemannic with Swabian traits; C is presumably Swabian/Alemannic; B, though Bavarian, exhibits Middle German influence; and DE are Bavarian. The concept evolution for recension A-1 was: Middle German Alemannian Bavarian.

Further inferences for provenience determination are drawn from scripts employed, but in our case this information adds little; for, although the scripts are readily identifiable and typical of Upper German chancery ducti, their hands remain unknown: A is textualis gothica; B a carefully composed extreme Gothic, blocky in form, absolutely even, and in chapbook format; $F$ a rapidly scripted Gothic cursive rife with errors; ${ }^{20} \mathrm{H} \mathrm{a}$ distinctive cursive. ${ }^{21}$

Intermediate between the purely philological and the cultural-historical lies the life history of the MS itself, i.e. its association with its owners and its physical properties. When coupled with the kinds of evidence introdu- 
ced thus far, such autobiographies are often helpful in localization.

A, designated Low (West) Alemannic/Swabian, is bound in red leather with metal clasps typical for volumes stamped mari(a) bound in the Nuremberg Carmelite Cloister between 1462-91 (see Table 3), and the marginal inscription on leaf $83 \mathrm{v}$ is in a script identified with Nuremberg, as is a marginal reference to that city (1424). ${ }^{22}$ Thus, despite its Alemannic origin, this, the oldest of the A-recension MSS, must have been conveyed to Nuremberg sometime prior to 1424 for subsequent binding as a collective codex. ${ }^{23}$ Leaves measure $20.5 \times 14 \mathrm{~cm}$. and are scripted in an area $18 \times 10 \mathrm{~cm}$. with 32 lines per side. A lacks the verse prologue.

B, Bavarian (Freising?) with Middle German features, stems from the Munich Hofbibliothek and contains the sigil: Ex Bibliotheca Sereniss. Vtriusque Bauariae Ducum 1618 on a paper sheet pasted on the title page. It was formerly cod. germ. membr. (Cat. No. 213). A leaf (SW 159:32 Gewan - 161:5 de hertoge) between leaves 44 and 45 has been cut away, but the text has been replaced from A-7 by Johannes Andreas Schmeller (April 14, 1846). The MS concludes with an abbreviated version of the so-called "First Bavarian Continuation" (leaves 66v:li.1-74r:li.25) and concludes (leaf $74 \mathrm{r}$ :li.26) with an insertion by a later hand: Ex Cron. fratris hermanni et martinj. Leaves measure $22.5 \times 15.5 \mathrm{~cm}$., are scripted in an area $17 \times 12 \mathrm{~cm}$., and contain 33 lines per side. ${ }^{24}$ B lacks the verse prologue, but contains the sermon ( $S W$ 115:11-117:10). The title on 1r, Daz ist diu kronick, in red is now barely legible. The text has red struck capitals, initials, and, occasionally, running text. According to Weiland, the $S W$ portion may date from c. 1314, but this appears highly speculative in view of the script. Leaf $66 \mathrm{v}$, the beginning of the Bavarian Continuation, is marked with an $x$ across the scripted portion of the side from li. 10 to the bottom of the leaf. B may have been scripted in Freising, but the evidence for this remains tenuous (cf. Table 3).

$\mathrm{C}$, indicated as Swabian/Alemannic, is a parchment MS bound in white pig skin in 1753, during the period Baron Gerard van Swieten was director of the Vienna Hofbibliothek (cf. Table 3). ${ }^{25}$ The spine reads: $C H R O N I C$. ROMAN. IMPERAT. with the older signature COD. MS. HIST. PROF. $D C X X X I$. On leaf $1 \mathrm{r}$ (bottom) is the old Ambras signature, MS. AMBRAS. 262 , in brown ink. The "First Bavarian Continuation"' commences on leaf $72 \mathrm{v}: \mathrm{li} .14$ and concludes with leaf 81v:li. 24, while "The Second Bavarian Continuation" (to 1348) begins on leaf 81v:li. 25 and concludes with leaf $84 \mathrm{v}$, the final leaf. The MS is slightly damaged in the upper right hand corner of leaves 1-7, but the text is intact. The version in C lacks the verse prologue, but contains the sermon (SW 115:11-117:10). The text has red struck capitals, is in Gothic cursive by two hands (hand $1=$ leaf $1 \mathrm{r}-53 \mathrm{v}$ med., hand $2=53 \mathrm{v}$ med. $-84 \mathrm{v}$ ) with a change in illumination with extended capitals for the second hand, and is scripted on leaves measuring $20 \times 35.5$ $\mathrm{cm}$. In the left margin of $84 \mathrm{v}$ there is a reference to the earthquake in Villach (January 25, 1348): 1348 in conversione pauli (25.1), which sugge- 
sted to Weiland et al. that the MS originated in Carinthia, but the reasoning is specious: the event is cited in numerous sources, even Low German. More significant is the fact that $\mathrm{C}$ was originally in the library of Count Wilhelm von Zimmern, son of the noted historian, Count Froben Christoph von Zimmern (d. 1567), and last male heir, who deeded his library (1576) to Archduke Ferdinand von Tirol (1529-1595). Upon the death of Archduke Sigismund Franz von Tirol (25 June 1665), this Ambras collection, including the Zimmern collection, fell to Kaiser Leopold I and thereby to the Hofbibliothek. The Zimmerische Kronik, composed (1564-66) by Count Froben and his amanuensis, Hans Müller, is distinctly Alemannian/Swabian, originated in Messkirch, and betrays the dialect of the Rottweil-Oberndorf area. ${ }^{26}$ The Count's interest in universal histories would certainly have led him to have prized possession of C, a MS from perhaps but a century prior to composition of his own chronicle, and he may well have employed it as a source in the compilation of his own chronicle.

D, decidedly Bavarian (Ingolstadt-Neuburg?), belongs among the MSS of the Bibliotheca Palatina which were brought to the Vatican Library in 1623 (leaf 5r has the insertion: in hac Bibliotheca Vaticana anno 1758 ... Joan. Antonius Hirschman Sacerdotus secularis Austriacus Viennensis describsit librum hunc.) and which were returned to Heidelberg in $1816 .{ }^{27}$ It has the binding of Pope Pius VI. The former registry number (575) on the spine has been crossed out, and leaf 157v has the owner's designation:Das půch ist clasen künzmuller while $232 \mathrm{v}$ has the scribe's signum: Kaczperger anno $C x x i i j^{\circ}$. Leaves measure $13.5 \times 20.8 \mathrm{~cm}$., have a scripted area of 17.5 $\times 11.5 \mathrm{~cm}$., and $32-36$ lines. The $S W$ script is a careless Gothic cursive by several (4?) hands. There are red initials, red struck letters in verse initial position, red punctuation designators, and red suprascripts, cf. Table 3. The "First Bavarian Continuation" follows (leaf 93v:li. 5-106r) upon the $S W$, but is incomplete, concluding with the reign of Heinrich VII. This version of the $S W$ begins without the prologue and lacks the sermon.

$\mathrm{E}$, also decidedly Bavarian, is found at the end of a collective codex and is followed by the "First Bavarian Continuation" (leaf 251va:li.4-261rb:li.15) and "Second Bavarian Continuation" (leaf: 261rb:li.15-262vb). ${ }^{28}$ This paper MS bound in leather has an ex libris sigil (Ex fructibus legati Henrici de Barckhaus Cons. Imp. Auli.) over which is found 16. POST NVBILA PHAEBUS. 34 and under which stands: ERHARDUS A MVCKENTHALL IN HAECKSENNACKHER. Erhard von Muggenthal (d. 1638), the MS' earlier owner, belonged to the Upper Palatinate nobility of Muggenthal in Altmühl-Jura. The Hexenagger (Riedenburg) title was conferred upon the family in 1529 by Duke Wilhelm of Bavaria. ${ }^{29}$ Leaves measure $29 \times 21.4 \mathrm{~cm}$. with $24-26$ lines, and the scripted area is bicolumnar. The script is careful Gothic cursive reminiscent of that for I and by one hand. The paper has the common ox head watermark, and there are drawings (18th century?) of human figures with a 
dog on leaf $263 \mathrm{r}$, see Table 3 . E also lacks the verse prologue.

Of particular note is the recorded (leaf $121 \mathrm{v}-122 \mathrm{r}$ ) reconciliation agreement between Albrecht Achilles von Brandenburg and the city of Nuremberg (1452/52). This text is presumably a draft and was inserted by another hand. Inclusion of this notice appears to point to Nuremberg as a possible provenience for this version of the $S W$.

F, deemed basically Middle German (Thuringian?) with Bavarian features - though some scholars have suggested the reverse, contains $S W$ (leaf $80 \mathrm{ra}-144 \mathrm{v}:$ li. 2) followed by the "First Bavarian Continuation" (leaf 144va li. 2-153ra: li. 23) and the "Third Bavarian Continuation"' (leaf 153ra: li. 23-158vb). These texts are inserted between a catalogue of popes (leaves $79 \mathrm{r}, 166 \mathrm{v}, 167 \mathrm{r}-\mathrm{v}$ ), the latter from Otto von Freising's chronicle (cf. Table 3). ${ }^{30}$ The "Third Bavarian Continuation", is unique to this MS, originated in Bavaria, and places major emphasis on Earl Friedrich of Thuringia. The codex, composed of two parts $(I=79 r-v-167 r-v)$, was bound as a unit in the second half of the 15 th century and derives from the cloister of Benediktbeuren: several pages bear the running head, Iste liber est Monasterij Benedictpewren, by another hand which also provided the table of contents on the frontispiece: Actus et processus quidam contra duces Bavariae anno 1423 propter querras ipsorum contra Monasteria. Chronica quedam in vulgari ab initio mundi usque ad tempora Ludovici imperatoris, which refers to the contents of Parts I and II respectively. On the spine stands: Processus contra Duces Bavar. On the leather binding frontis stands: Chronica principium in Wlgari et alia. $N$ XXII.. Leaves measure $29 \times 20 \mathrm{~cm}$., and the $S W$ text is bicolumnar with 39 lines. The verse prologue is lacking, but the sermon is included. Capitals are red, as are illuminations, and the initial leaf (80r) of the $S W$ has the rubric: Dit ist ein kronike von allen konigen vnd pabesten vnd wie alle konigrich erst her komen sint over both columns scripted by the same hand as the text. The reference to Benediktbeuren is found at the bottom of the same side under both columns. This version alone of the A-1 recension contains interpolations from Martin von Toppau's Chronicon pontificum et imperatorum, but they are not related to interpolations from the same source in MSS C 18, 19, 20-22. On the bottom edge of leaf 113ra is found the following addition to $S W$ 146:1: $Z u$ den zeiten wart gepauwen daz closter sant Benedictpaurn von drein prudern und geweihet von sant Bonifacio von Mainz dem heiligen erzbischof, cf. $S W 146: 36 \mathrm{f}$. Weiland ${ }^{31}$ believed that $\mathrm{F}$ was composed in Bavaria, conveyed to Thuringia and rescripted, and then returned to Bavaria (Benediktbeuren) and rescripted: hence its essentially Middle German (Thuringian?) character and note the "Third Bavarian Continuation", but this thesis has been contested, ${ }^{32}$ though the linguistic evidence supports it.

G, Middle German and Bavarian, contains only the $S W$ (leaf 1r-86r) and the "First Bavarian Continuation" (leaf $86 \mathrm{r}-93 \mathrm{v}$ ), is scripted by five hands (h1 = 1r-12v, h2 = 13r-20v:li. 10, h1 = 20v:li. 10-32, h3 = 21r-24v, h4 = 
25r-68v:li. 15, h5 = 68r:li. 16-86r) in Gothic cursive, and was known, but unavailable to Weiland, as it was temporarily lost, though later recovered. It was originally in the possession of Hans Philipp Werner von und zu Aufsess (1801-1872), the noted historian and founder of the Germanisches Nationalmuseum, Nuremberg, to which he gave his library and art collection: the MS thus has a well established Bavarian pedigree (see Table 3) ${ }^{33}$ We have already noted the linguistic affinity of $F$ and $G$. $G$ also lacks the verse prologue.

The $\mathrm{H}$ fragment, a copy of $\mathrm{I}$, is Middle German/Bavarian and contains the $S W$ as the first section (leaf 1ra-13rb) of a collective codex which also contains (leaf $15 \mathrm{ra}-339 \mathrm{vb}$ ) Andreas von Regenburg's Chronica pontificum et imperatorum Romanorum in the the German translation of Leonard Heff (see Table 3).$^{34}$ Leaves measure $37.5 \times 25.5 \mathrm{~cm}$. with a scripted area of $24.5 \times 17.5 \mathrm{~cm}$. and have 40 lines. Leaf $14 \mathrm{r}-\mathrm{v}$ is blank. Capitals (e.g. 1r) are illuminated in red and/or blue, and there are multicolored illuminations on $1 \mathrm{r} . \mathrm{H}$, as I, contains $S W$ through c. 28 without the verse prologue. $\mathrm{H}$ is bound in brown leather and has the following inscription in four lines on the spine: Fr. Andreae Rat /isb. Chronicon. /germ. /Sac. XV. The frontispiece bears the number 570 whence Massmann ${ }^{35}$ took his numbering. Leaf $1 \mathrm{r}$ bears the following library mark by a 16th century hand: Monasterii $S$. Emmerami Ratisbonae: $\mathrm{H}$, scripted in a Gothic cursive, was in the possession of the St. Emmeram Cloister, Regensburg.

I, also scripted in Gothic cursive, is Middle German/Bavarian and a collective codex with basically the same description as $\mathrm{H}$ : it, too, presumably belonged to the Benedictine cloister of St. Emmeram. Leaves measure $45 \times 28.5 \mathrm{~cm}$. with a scripted surface $25.5 \times 19 \mathrm{~cm}$. and 37 lines. Contents of I are in the same order as those in H: $S W$ (2ra-13ra), Chronica pontificum et imperatorum Romanorum (17ra-249rb), but I also contains a translation of a portion of Andreas von Regenburg's Concilium Constantiense (249va-289vb), Chronica Husitarum and history of emperors Friedrich III and Maximilian (290ra-rb), and a papal history from Nicolas V (1447-1455) to Paul II (1464-1471), the terminus ante quem for compilation of the codex. ${ }^{36}$ The Chronica pontificum by Andreas (c. 1380-1438) was translated by Leonard Heff of Eichstätt at the request of Erasmus Träiner of Regensburg in 1470/71. On leaf 290rb it is noted:Amen. Leon. He., and on leaf 228rb stands: Das buech ist geendet An Sandt Pauls abent Anno Domini Mcccclxxj.Jare 1471. Heff entered the University of Vienna in 1459 and acquired the B.A. in 1461, whereupon he apparently resided in Regensburg as a cathedralis. He also authored a universal chronicle, Imago mundi (Clm 26632), from 1470, which contains a copy of the Speculum historiale. Träiner is the name of a patrician family in Nuremberg.

With respect to dialect, probable (intermediate) provenience ${ }^{37}$ and date of compilation of the individual MSS, we summarize our conclusions thus far as follows: 


\begin{tabular}{|c|c|c|c|}
\hline \multicolumn{4}{|c|}{ DIAGRAM I } \\
\hline MS & DIALECT & $\begin{array}{l}\text { (INTERMEDIATE) } \\
\text { PROVENIENCE }\end{array}$ & Compil. Date \\
\hline 1 & (A) Low (West) Alemannic/Swabian & Nuremberg & c. 1470 \\
\hline 2 & (B) Bavarian (Freising?)/M. Germ. & Freising? & c. 1450 \\
\hline 3 & (C) Swabian/Alemannic & Zimmern & c. 1460 \\
\hline 4 & (D) Bavarian (Ingolstadt-Neuburg?) & Ingolstadt? & c. 1450 \\
\hline 5 & (E) Bavarian & Nuremberg & c. 1450 \\
\hline 6 & (F) Bavarian/M. Germ. & Benediktbeuren & c. 1420 \\
\hline 7 & (G) Bavarian/M. Germ. & Aufsess? & c. 1450 \\
\hline 8 & (H) Bavarian/M. Germ. & Regensburg & c. 1470 \\
\hline 081 & (I) Bavarian/M. Germ. & Regensburg & c. 1470 \\
\hline
\end{tabular}

In terms of dialect and (intermediate) geographical provenience, the MSS of the A-1 recension fall into two distinct groups: Alemannic (Swabian) and Bavarian (Middle German), cf. Table 2 and fn. 9 for their filiation. Many of the Bavarian versions (FHI) are known from Benedictine foundations (St. Emmeram, Benediktbeuren fl. 1295-1803). Moreover, with the exception of $\mathrm{F}$, the Bavarian versions generally stem from the Upper Palatinate and exhibit Middle German (Thuringian?) influence. With the exception of the fragments, $\mathrm{HI}$, all Bavarian versions and $\mathrm{C}$ contain the "First Bavarian Continuation"' (incomplete in D), while the "Second Bavarian Continuation"' is found in CE, and the "Third Bavarian Continuation" is unique to F. All versions in the A-1 recension lack the verse prologue, though most (ABCEFG) contain the sermon ( $S W$ 115:11-117:10): MSS 2-081 (8) clearly represent the same tradition. With the exception of DE, all Bavarian versions exhibit Middle German influence, but this does not hold for the Alemannic versions AC. According to their filiation (Table 2 and fn. 9), Bavarian versions do not necessarily derive from the Alemannic versions (AC) directly, though $\mathrm{BC}$ have a common source, presumably Alemannic as witnessed by MS 021 . These stemmatic conclusions are supported by the linguistic evidence, cf. Diagram I. BC form the bridge between the Alemannic and Bavarian traditions of the A-1 recension. $F$ and $G$ are both linguistically and stemmatically related and form the terminal node of a tradition deriving from the $A$ prototype with $\mathrm{DE}$ as intermediaries. The fragments $\mathrm{HI}$ are correctly related by Herkommer ${ }^{38}$ to $\mathrm{B}$. The stemmatic, dialectal, and provenience evidence conspire to support the thesis that the (dialectal) concept evolution of the A-1 recension was: Middle German $\rightarrow$ Alemannic $\rightarrow$ Bavarian. $\mathrm{DE}$ alone are exclusively Bavarian, while all other Bavarian versions (BFGHI) reveal Middle German influence: Middle German versions (or scribes in the case of F) may have been employed referentially in the composition of these versions. For the presumed period of composition of $S W$ texts in A-1 MSS, it is difficult to discern a wide range of dialectal difference between Middle German and Alemannic. Nevertheless, upon more extensive investigation, Middle German influence may well be de- 
tected in $\mathrm{AC}$.

We conclude that the A-1 recension represents the $S W$ at its earliest remove from Eike's concept or close derivatives therefrom and that, in view of the above, the $S W$ was therefore conveyed, via Middle German intermediaries, first to Alemannia and then Bavaria. As the first vernacular prose chronicle, it is only natural to assume that the $S W$ attracted wide attention. The fact, as revealed by the distribution of recension A-1 MSS, that it seemingly attracted most significant initial attention in Upper Germany - more than in Middle Germany or the Low Germany of its origin, is simultaneously striking and enigmatic. The course of diffusion of the $S W$ is, however, paralleled by that for Eike's Sachsenspiegel (c. 1220-30), the ultimate model for the Deutschenspiegel (c. 1250) and its successor, the Schwabenspiegel (c. 1270), both presumably stemming from Augsburg. ${ }^{39}$ Southern Germany was obviously starved for the legalistic and historiographic products of the north, particularly as they found perfection at the hands of Eike. The decided expansion of the historical horizon by the Crusades and trenchant political conflicts at the conclusion of the 12 th century engendered a distinct demand for universal chronicles and a broader basis of legalistic expression; the $S P$ and $S W$ answered these demands. We note that, excluding fragments, there are over 400 known MSS of the Schwabenspiegel. The $S W$ achieved broad popularity in Upper Germany until it was gradually supplanted by Martin von Troppau's (Martinus Polonus) Chronicon pontificum et imperatorum (post 1277 ) and the Flores temporum (post 1292). We note that F contains interpolations from the Chronicon and that the $S W$, like the Flores, also contains extensions (First, Second, Third Bavarian Continuations) to ensure currency.

The Saxon Universal Chronicle was thus first conveyed to Alemannia (Swabia) and thence Bavaria via Middle Germany in precisely the same manner as the Sachsenspiegel, a conclusion drawn from comparison of the linguistic and textual evidence, the standard and well-established procedure in the investigation of manuscript traditions. The vector for its transmission was quite probably the solid chain of Benedictine foundations. From the cloisters in which scripted, the $S W$ MSS soon attracted the interest of a nobility for whom an historical record which placed near contemporary events in line with those of Greece and Rome must have had considerable appeal.

Having determined that the A-1 recension represents the earliest extant version of the $S W$ and having shown that the recension's concept and immediate predecessor was Middle German, we conclude that the only possibility for reconstitution of a proximate concept and thereby an "original" (when devoid of a Low German version in recension A) is comparison of the A-1 MSS with an eye to reconstitution of Middle German features. Determination of the earliest recension, the course of diffusion of its MSS in filiation, and their dialectal proveniences defines the procedure 
for reconstitution of a concept.

More precise determination of the composition date of the Eike concept and that of the A-1 recension concept, as well as the MSS in the recension, is afforded by examination of the presumed sources of this recension. However, as we indicated at the outset, implementation of source information does not provide secure information as to geographical origin. As shown by the Source Outline, ${ }^{40}$ the majority of non-Classical sources employed in A-1 are from the 12th century: Annales Palidenses (1182), Frutolf-Ekkehard (1125), Kaiserchronik (c. 1150), Decretum Gratiani (c. 1140), Gilbert's Chronicon (c. 1189), Honorius' De imagine mundi (c. 1130), Annales Magdeburgenses (1188). Those sources among these which are indigenous to Germany are, of course, primarily Saxon. Nevertheless, these sources were employed throughout East Middle Germany. We note that the Annales Magdeburgenses, which cite Frutolf-Ekkehard, were subsequently used in composition of the Annales Pegaviensis (Cloiser Pagau near Leipzig). ${ }^{41}$ Other than the distinctly later interpolations from Martin von Troppau's Chronicon in $\mathrm{F},{ }^{42}$ the latest sources used in recension A-1 are the Annales Stadenses (1256), the Chronicon Sancti Michaelis Luneburgensis (1229), and the Sachsenspiegel (c. 1220-30) itself. Of these, the only sources dating from before Eike's putative death date are the Sachsenspiegel and the Chronicon Sancti Michaelis Luneburgensis. Thus, Eike's concept must date from after c. 1230, while the A-1 recension concept dates from after 1256 and before composition of MS A (c. 1380?), We infer that the concept for the A-1 recension was probably composed c. 1256-c. 1350: the conclusion of "The First Bavarian Continuation" in its most complete form in MS 021. A version reconstituted from the MSS of this recension should therefore be consonant with the linguistic features of Middle German from this period.

Having defined the procedures for reconstitution of an intermediary concept, inferential dating from sources employed and MS composition dates permit determination of the linguistic period which that reconstruction should reflect.

In our examination of the case history of the A-1 recension of The Saxon Universal Chronicle we have not only demonstrated the precepts of textual reconstruction, but also observed how the language of a text is dialectally shifted to suit the particular speech habits of the area or areas in which the text achieves prominence as a literary document: literary and linguistic constraints are reciprocal in influential force.

The University of Michigan

T. L. MARKEY

\section{Notes}

1. For the numerous titles given the $S W$ prior to Weiland's (1876) edition, see Friedrich Pfeiffer, Untersuchungen über die Repgowische Chronik (Breslau, 1854), p. 28. Previously, 
the tradition of ascribing the SW to Eike had more fantastic than factual grounds; reasoning for ascription was precipitously inferential; as Eike was known to have authored other, similar chronicles with Low German (Saxon) orientation, he must therefore have authored the $S W$. Cf. Karl Zeumer, "Die Sächsische Weltchronik, ein Werk Eikes von Repgow", Festschrift Heinrich Brunner zum 70. Geburtstag (Weimar, 1910), 135-74, 839-42; Hans Voltelini, "Der Verfasser der Sächsischen Weltchronik", Forschungen zu den deutschen Rechtsbüchern, II, ed. by Anton Pfalz and Hans Voltelini, (SbbAkadWien, 201, 4.-5., Abh.) (Vienna and Leipzig, 1924), 5-60. Note Hans F. Massmann's unblushing positivism, a mere portion of which we shall cite here, in the preface to his edition of MS B-16, Das Zeitbuch des Eike von Repgow in ursprünglich niederdeutscher Sprache (Bibliothek des literarischen Vereins Stuttgart, 42) (Stuttgart, 1857), v: "Dass ich Eike's Arbeit hier und im Buche selbst aber nicht nur als das erste und älteste deutsche, sondern auch als das erste durch und durch an Gesinnung deutsche Zeitbuch bezeichnet habe, wird die frische Hauch, der das Ganze wohlthuend durchweht, nicht minder die darüber wie über seine Quellen geführte Untersuchung rechtfertigen". By the 17th/18th century, ascription to Eike had become part of popular tradition. Note the following (17/18th century) inscription on the title leaf of C-22: Chronicon heren Ecken von Repgow, de den Sassenspegel thosamede gebracht hefft.

2. See, e.g., Gustav Ehrismann, Geschichte der deutschen Literatur bis zum Ausgang des Mittelalters, II:II (Munich, 1935), p.437f.; Wilhelm Scherer, Geschichte der deutschen Litteratur, 6th ed. (Berlin, 1891), 231. Eike, a juror from the vicinity of Magdeburg, is documented six times $(1209,1215,1218,1219,1224,1233)$ in sources from Anhalt, but precise details about his person and station are lacking. It is presumed that he was born c. 1180 and died c. 1234/5, making the $S W$ the work of his final years. Both his father and son were jurors, and Eike is known to have served Count Hoyer von Valkenstein (1211-1251) in this capacity, see infra and cf. Scherer, op. cit.,p. 739 and Karl August Eckhardt, Der Sachsenspiegel: Eike von Repgow und Hoyer von Valkenstein (Germanenrechte, N.F., Abt. Land- und Lehnrechtsbücher, Bd.I, T.4) (Hannover, 1966). Composition dates for the $S W$, as well as the Sachsenspiegel $(=S P)$, are necessarily approximate. Table 1 clearly indicates early diffusion of the $S W$ to Upper Germany, and we note the significally parallel diffusion of the $S P$; it served as the model for the two foremost Upper German legal texts, the Deutschenspiegel and its successor, the Schwabenspiegel, as well as the Rechtsbuch nach Distinktionen, or socalled "Expanded" Schwabenspiegel, while, although the anonymous Middle German (Thuringian) Rechtsbuch (c. 1224-27) from Mühlhausen is contemporaneous with the $S P$, it was certainly compiled without knowledge of Eike's work, see Karl August Eckhardt, Der Deutschenspiegel; seine Entstehungsgeschichte und sein Verhältnis zum Schwabenspiegel (Weimar, 1924). Eike's authorship of the $S P$ has long been recognized from its highly formulaic and stereotypic preface:

Nu danket al gemene deme van Valkenstene

de greve Hoier is genant, dat an dudisch is gewant

dit buk dorch sin bede: Eike van Repchowe it dede;

The preface also states that Eike first composed the $S P$ in Latin, subsequently translated into German. Thus, the $S P$ was enormously influential in forging the evolution of German codification, particularly in Upper Germany, while various stipulations stemming from the $S P$ were enforced in Thuringia and Anhalt until 1900.

3. Ludwig Weiland, Die Sächsische Weltchronik (Monumenta Germanicae historica, Deutsche Chroniken, II:I) (Hannover, 1876), 20-33. The Frutolf Chronicle, so named after Frutolf von Michelsberg, as redacted by Ekkehard von Aura, has been edited by Georg Waitz, Chronicon universale (Monumenta Germanicae historica, Scriptores VI) (Hannover, 1844), 33-267. For the Annales Palidenses, see the edition by G. H. Pertz, (Monumenta Germanicae historica, Scriptores XVI) (Hannover, 1859), 51-98. Cf. Hubert Herkommer, Überlieferungsgeschichte der "Sächsichen Weltchronik". Ein Beitrag zur deutschen Geschichtsschreibung des Mittelalters (Münchener Texte und Untersuchungen zur deutschen Literatur des Mittelalters, Bd. 38) (Munich, 1972), 4-8, where a plethora of secondary critical literature is cited. A survey of the sources alleged by Weiland, op. cit., 20-33, is appended in the Source Outline.

4. Hermann Ballschmiede, Die Sächsische Weltchronik (Norden, 1914); "Die Sächsische Weltchronik," Niederdeutsches Jahrbuch 40(1914), 81-140; cf. the review by Adolf Hofmeister, Historische Zeitschrift 115 (1916), 207. This constitutes Ballschmiede's Berlin dissertation directed by the venerable Gustav Roethe, thirty-four pages of which are concerned with MS traditions and the remainder with a rather feeble attempt to prove Eike's authorship.

5. Karl August Eckhardt, Rechtsbücherstudien. 2. Die Entstehungszeit des Sachsenspie- 
gels und der Sächsischen Weltchronik (Abh. d. Gesellschaft d. Wissenschaften zu Göttingen, Phil.-hist. Kl., N.F. 23:2) (Göttingen, 1931).

6. Herkommer, op. cit..

7. Preeminently by Karl-Ernst Geith, "Zur Überlieferungsgeschichte und Textgestalt der Sächsischen Weltchronik aus Anlass von Hubert Herkommers Buch", $P B B(T) 96(1974)$, 103-19 and Gerhard Cordes, rev. of Herkommer, op. cit., Niederdeutsches Jahrbuch 96 (1973), 181-90. Of greatest import here are H.'s arguments for the priority of the C-recension. The argumentation is essentially twofold: the demands of brevitas among medieval historiographers and the manner and greater extent to which the Kaiserchronik $(=K c h r$.) is used in C vs. AB, see Source Outline. The brevitas argument entails subsequent condensation of an original: as $\mathrm{AB}$ are shorter than $\mathrm{C}, \mathrm{AB}$ represent a subsequent condensation of $\mathrm{C}$, and $\mathrm{C}$ takes priority over AB. Here, as Cordes (p. 189) shows, H. (pp. 225, 229) contradicts himself. He reasons that MS A-6 (F) is later than MSS A 1-5, but shows that A-6 is expanded by interpolations from Martin von Troppau's Chronicon. Expansion, rather than condensation was the rule in the later redactions of medieval historiographic works. Witness the Bavarian Continuations in SW, extension of Frutolf by Ekkehard, extension of the Chronica S. Petri Erfordensis (moderna), etc. In fact, it is virtually impossible to find supportive evidence for H.'s argument, but cf. H., op. cit., 234-40. H. divides the C-recension into $\mathrm{C}^{1}$ and $\mathrm{C}^{2}$ (MSS 20-22 vs. 18, 19, 23, 24 resp.) and proposes that the mixture of poetry and prose, H.'s "Prosimetrum", in passages deriving from the Kchr. in the former were the basis for their incorporation as prose in the latter $\left(=\mathrm{C}^{2}\right)$. Geith demonstrates that many such passages in $\mathrm{C}^{2}$ cannot possibly derive from correspondents in $\mathrm{C}^{\prime}$ and concludes that $\mathrm{H}$. has only succeeded in demonstrating that $\mathrm{C}^{\mathrm{l}}$ and $\mathrm{C}^{2}$ are based on the same version of the $K c h r . \mathrm{H}$. then argues that remnants of $K c h r$. interpolations in $\mathrm{AB}$ stem from $\mathrm{C}^{2}$, but Geith (p. 111) explodes the validity of H.'s citations. Finally, Geith convincingly shows that H.'s attempts to prove that C consistently presents difficilior readings are unfounded. Geith concludes his critique, as does Cordes, with the assertion that $\mathrm{A}$ takes priority over $\mathrm{BC}$ and that Eike authored the chronicle.

8 . The $S W$ has not been re-edited since Weiland, who based his edition on C-24, the earliest and least corrupt of the C-recension MSS, but Weiland filled lacunae in C-24 from B-17, which is closer dialectally to C-24 than B-16 and which is less corrupt than B-16. Moreover, B-16 had been edited by Massmann, op. cit., fn. 1. References in the format (SW 88:9-21) are to pages: lines in Weiland's edition. Weiland's determination of the priority of the A-recension (MSS A 1-8 in particular) over BC was based on the early termination (Battle of Mölln, January 1225) of these manuscripts, cf. Herkommer, op. cit., 14-15. Weiland regarded subsequent recensions as expanded versions of $\mathrm{A}$, while, as we noted, Herkommer has argued the opposite. Weiland, op. cit., p. 49, also advanced rather spurious pragmatic grounds for the priority of A, e.g.: "das werk so rasch wie möglich der öffentlichkeit zu übergeben" is seen as the author's intention for the brevitas of A. Weiland intended his edition for the historian, not the philologist, and the linguistic portion of the apparatus is therefore exclusive of minor phonological (dat:daz), lexical, and syntactic variations; lectiones were selected quite subjectively, but with an eye to historical, rather than philological significance, and there is no provision for comparison with alleged sources. Nevertheless, Weiland's edition is one of the outstanding volumes in the Monumenta: it forms the basis for all further investigation and editorial activity. The author commenced work toward a critical variorum edition of the A-recension (MSS 1-8) in 1970 and is grateful for a Canaday Research Fellowship from Harvard University (Summer, 1970), which permitted him to view MSS in situ and to collect microfilm copies of each, a Horace H. Rackham Research Grant (387064) from the University of Michigan (1975), which permitted completion of transcriptions and copy-flow reproductions of the MSS, and a stipend from the National Endowment for the Humanities to attend the Southeastern Institute of Medieval and Renaissance Studies (Summer, 1975), where the author profited from discussions about editorial principles and apparatus with Professor Petrus Tax. Dr. Karl-Ernst Geith (Freiburg) has informed the author (per litteras, 11/19/75) that there are currently no other plans for a new edition of the $S W$. The author's edition, now nearing completion, will soon be prepared for publication.

9. Table 2 is adapted from Herkommer, op. cit., 267, cf. p. 245. Weiland, op. cit., 19, provides the following, immediately comparable, stemma for MSS A 1-7, but omits MS A-8 with the reasoning that: "Ds hs. fragment 8 näher einzuordnen geht nicht und würde auch nicht verlohnen".

Thus, in SW 146:14, MSS 1-3 have pelagii (cf. MS A 021 = belage), while MSS 4-7 have unde die wirdichait (wird MS 5). In MSS 2-3, the First Bavarian Continuation terminates with 1314, but in MS 021 with 1350, cf. fn. 11. MSS 2-3 show the following interpolation in c. 144 


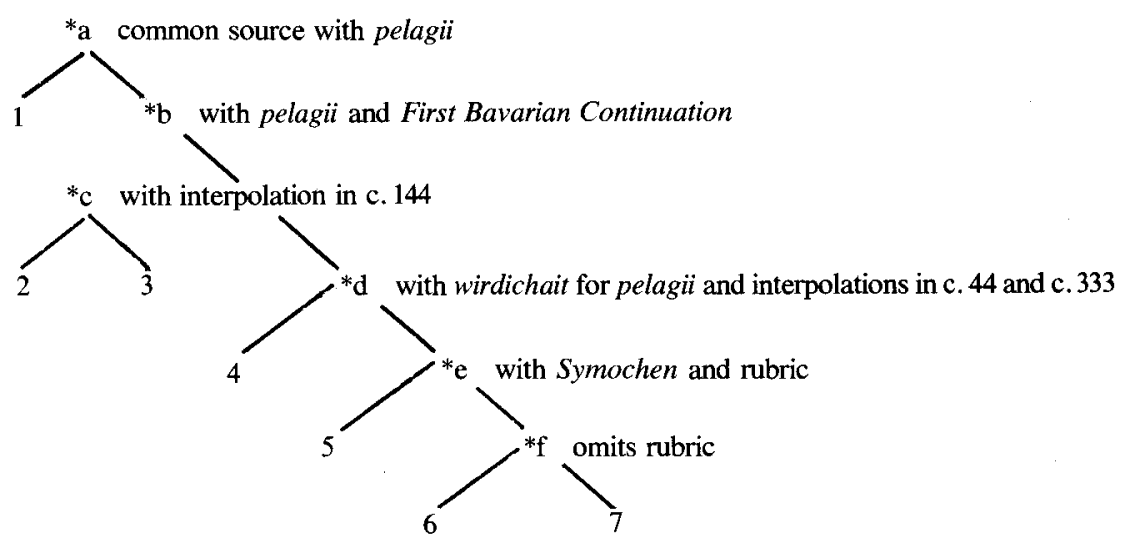

(SW 156:31): und leit ze Regenspurch datz sant Hemmeran (auf dem chor = lacking 2), while MSS 4-7 have common interpolations in c. 40 ( $S W$ 97:39-43 = Nero's Pregnancy) and c. 333 ( $S W 232: 35$ = Foundation of the German Order), where the Nero episode is not specifically taken from the Kaiserchronik, cf. Herkommer, op. cit., 230. In SW 244:30f., MSS 5-7 have reinterpreted sinen om in bi sinen om, den koning van Denemarken as Si(y)moch(th)en, king of Denmark. The evidence given by Weiland for construction of the stemma is, of course, insufficient, though he certainly restricted himself to the most telling deviations, and his stemma is supported by Herkommer, op. cit., 245-66, who presents further data and asserts (pp. 262-65) that MS 8 is a copy of MS 081 and that both in turn derive from MS2, as both contain the particular readings and discontinuities in MS2. While we thus agree with Weiland's and Herkommer's corroborative reconstruction of the A-1 stemma, we cannot agree with Herkommer's construction of the A-2 stemma (MSS9-12a) and the conjoined equivalence of recensions $A-1$ and $A-2$, nor with his subordination of the $A-r e c e n s i o n ~(A-1$ and $A-2)$ to $B$ and $C$, cf. fn. 7 .

10. The four oldest (13th century) MSS are contained in the $B$ and $C$ recensions and all are Low German: 16, 17, 24. Nevertheless, all represent textual extensions beyond the MSS of the A-1 recension, cf. Source Outline and fn. 7. Moreover, the A-1 recension MSS contain misinterpretations of Low German "substrate" forms, and, given the assumption of the primacy of MSS 1-081, this proves that their concept was based on a Low German version: e.g. MLG Kote (kotte, kate), "hut", is misinterpreted as HG kot, "mud".

11. MS 021 (see Tables 1-3) was unknown to Weiland and was discovered in 1882 by August Bernoulli, see Bernoulli, "Die Basler Handschrift der Repgauischen Chronik", Anzeiger für Schweizerische Geschichte 13 (1882), 25-30, 41-52; Herkommer, op. cit., 42-6. The dialect of this text is distinctly Alemannic. This collective codex of 231 leaves contains: extracts from Rudolf von Ems' universal chronicle (1ra-14ra), fragment of a "Trojan" poem (14ra-17va), $S W$ (17vb-156-vb) with additions specific to Basel, Lamprecht's Alexander (22vb-67va), the "First Bavarian Continuation" through 1350, the most complete version (157ra-157vb), the Annales Pairisiensis (1422) from the Alsatian cloister (179v180r), short notices from the years 1349, 1408, and 1453 (181r), the chronicle of Erhard von Appenwiler (181v-231r). Erhard, documented in Basel in 1429, composed his chronicle for the period $1439-71$ and was obviously a careful reader of the $S W$, for many notations to the $S W$ text in 081 are inserted by his hand. MS 021 initiates inclusion of the continuations and contains the fullest version of the "First Bavarian Continuation", a misnomer, for the continuation is chiefly concerned with events in the Basel-Strassburg area and should be termed the "Alsatian Continuation". Note inclusion of the Annales Pairisiensis. In comparison with the other MSS of the A-1 recension, 021 is fragmentary (see Table 1) and includes additions specific to Basel, as well as other unique additions (e.g. die bebste vnd die bischoff kruchen vnder die erden als die frösche so si gottes dienst woltten begann, cf. $S W$ 116:20f.). For these reasons it has been excluded from consideration here.

12. Cf. Werner Besch, Sprachlandschaften und Sprachausgleich im 15. Jahrhundert. Studien zur Erforschung der spätmittelhochdeutschen Schreibdialekte und zur Entstehung der neuhochdeutschen Schriftsprache (Bibliotheca Germanica, II) (Munich, 1967), 76-9; 
Hermann Paul und Walter Mitzka, Mittelhochdeutsche Grammatik, 19th ed. (Tübingen, 1966), Arts. 2-4, 12, 28, hereafter cited as $M G$. Herkommer (per litteras, 9/10/71) informed the author that he was not concerned with dialectical definition and in this matter relied solely on secondary sources.

13. Friedrich Kauffmann, Geschichte der Schwäbischen Mundart in Mittelalter und in der Neuzeit (Strassburg, 1890), 88-9, 174.

14. Besch, op. cit., 117-21; Kauffmann, op. cit., 201.

15. Besch, op. cit., 83 .

16. $M G$, Art. 180.2 , Anm. 5 .

17. Besch, op. cit., 75-6.

18. Besch, op cit., 104-5.

19. $M G$, Art. 30, Anm.; Eberhard Kranzmayer, Historische Lautgeographie des gesamtbairischen Dialektraumes (Vienna, 1956), Art. 16c and Map 12.

20. Cf. Erich Petzet and Otto Glauning, Deutsche Schrifttafeln des IX. bis XVI. Jahrhunderts aus Handschriften der Bayrischen Staatsbibliothek in München, V (Leipzig, 1930), Tafel LVII.

21. Petzet and Glauning, op. cit., Tafel LXVII.

22. Erinst Kyriss, Nürnberger Klosterinbände der Jahre 1433 bis 1525 (Erlangen, 1940), Tafel 9. The author is indebted to the Herzog-August Bibliothek for permission to view the MS and to make photo copies.

23. Herkommer, op. cit., 39-41.

24. Herkommer, op. cit., 41-2. The author is grateful to Dr. Hauke, Handschriftenabteilung, Bayrische Staatsbibliothek, for permission to view the MS and to make photo copies.

25. The author is grateful to Dr. Laurent Strebl, Österreichische Nationalbibliothek, for permitting him to view the MS and to make photo copies. See Massmann, op. cit., 76-7; Hermann Menhardt, Verzeichnis der altdeutschen literarischen Handschriften der Österreichischen Nationalbibliothek, I (Berlin, 1960), 19, 29; Herkommer, op. cit., 46-9.

26. Zimmerische Chronik, ed. K. A. Barack, IV (Bibliothek des literarischen Vereins in Stuttgart, XCIV) (Tübingen, 1869), 450-88.

27. The author is indebted to Bibliotheksrat, Dr. Wilfried Werner, Handschriftenabteilung, Universitätsbibliothek, Heidelberg, for permission to examine the MS and to make photo copies. See Karl Bartsch, Die altdeutschen Handschriften der Universitätsbibliothek in Heidelberg, I (Heidelberg, 1887), 147 (No. 266); Herkommer, op. cit., 49-51.

28. The author is grateful to Dr. Bück of the Stadt- und Universitätsbibliothek, Frankfurt, for permission to view the MS and to make photo copies. See Herkommer, op. cit., 51-4.

29. August Sieghardt, "Die Herren von Muggenthal im Altmühl-Jura", Die Oberpfalz. Eine Heimatzeitschrift für den ehemaligen Bayrischen Nordgau 47 (1959), 250-54.

30. Herkommer, op. cit., 55-7. Once again the author is indebted to Dr. Hauke of the Bayerische Staatsbibliothek for permission to view the MS and to make photo copies.

31. Weiland, op. cit., 341.

32. Herkommer, op. cit., 55 , fn. 56.

33. Herkommer, op. cit., 57-8. The author is grateful to the Germanisches Nationalmuseum for permitting him to examine the MS and to make photo copies. Note that Massmann's, $o p$. cit., edition of the $S W$ gives variants from $G$ under the listing A.

34. Herkommer, op. cit., 58; Weiland, op. cit., 7. The author is grateful to Dr. Hauke, Bayerische Staatsbibliothek, for permission to view the MS and to make photo copies.

35. H.F. Massmann, Das Zeitbuch, op. cit.

36. Herkommer, op. cit., 59-65.

37. The "intermediate provenience" is a term employed to designate the putative locus of a MS between the area in which presumably composed and the place in which it is currently housed, if different.

38. Herkommer, op. cit., 262-5.

39. Cf. fn. 2.

40. Via textual comparison (limitation of space prohibits exemplification) it was determined that Weiland's identification of Classical (e.g. Bede, Orosius) sources in the $S W$ (cf. Source Outline) is spurious, while his identification of German historiographic materials was largely without error with the probable exceptions of the Chronica Slavorum (c. 1150), Stader Chronicle (lost), and Magdeburger Gesta (lost).

41. W. Wattenbach, Deutschlands Geschichtsquellen im Mittelalter, 7th ed. (Stuttgart and Berlin, 1904), 386-7.

42. Herkommer, Überlieferungsgeschichte, op. cit., 56, 256. 
TABLE 1

SURVEY OF MANUSCRIPTS GROUPED ACCORDING TO RECENSION CLASS

$\mathrm{R}=$ recension, Date $=$ composition date of $\mathrm{MS}, \mathrm{FBC}=$ First Bavarian Continuation where $+/-$ denotes presence vs. absence, $\mathrm{SW}=$ page, line contents according to Weiland (1876) edition.

\begin{tabular}{|c|c|c|c|c|c|c|}
\hline $\mathbf{R}$ & MS & DATE & DIALECT & CONTENTS & FBC & MATERIAL \\
\hline A-1 & $\begin{array}{r}1 \\
2 \\
021 \\
3 \\
4 \\
5 \\
6 \\
7 \\
8 \\
081\end{array}$ & $\begin{array}{l}\text { 14th cent. } \\
14 \text { th cent. } \\
\text { 15th cent. } \\
\text { 15th cent. } \\
\text { 15th cent } \\
\text { 15th cent. } \\
\text { 15th cent. } \\
15 \text { th cent. } \\
15 \text { th cent. } \\
\text { 15th cent. }\end{array}$ & $\begin{array}{l}\text { Upper German } \\
\text { Bavarian } \\
\text { Alemannian } \\
\text { Upper German } \\
\text { Upper German } \\
\text { Bavarian } \\
\text { Bavarian } \\
\text { Upper German } \\
\text { Upper German } \\
\text { Upper German }\end{array}$ & $\begin{array}{l}\text { SW }(67: 1-244: 32) \\
\text { SW }(67: 1-244: 32) \\
\text { SW }(78: 21-243: 19) \\
\text { SW }(67: 1-244: 32) \\
\text { SW }(78: 11-244: 32) \\
\text { SW }(67: 1-244: 32) \\
\text { SW }(67: 1-244: 32) \\
\text { SW }(67: 1-244: 32) \\
\text { SW }(67: 1-87: 3) \\
\text { SW (67:1-87:32) }\end{array}$ & $\begin{array}{l}- \\
+ \\
+ \\
+ \\
+ \\
+ \\
+ \\
+ \\
+ \\
?\end{array}$ & $\begin{array}{l}\text { parchment } \\
\text { parchment } \\
\text { paper } \\
\text { parchment } \\
\text { paper } \\
\text { paper } \\
\text { paper } \\
\text { paper } \\
\text { paper } \\
\text { paper }\end{array}$ \\
\hline A-2 & $\begin{array}{c}9 \\
10 \\
10 \mathrm{a} \\
101 \\
102 \\
\\
11 \\
111 \\
12 \\
12 \mathrm{a} \\
121\end{array}$ & $\begin{array}{l}1400 \\
15 \text { th cent. } \\
15 \text { th cent. } \\
13 \text { th cent. } \\
14 \text { th cent. } \\
\\
14 \text { th cent. } \\
15 \text { th cent. } \\
15 \text { th cent. } \\
15 \text { th cent. } \\
15 \text { th cent. }\end{array}$ & $\begin{array}{l}\text { Upper German } \\
\text { Middle German } \\
\text { Middle German } \\
\text { Latin } \\
\text { Middle German } \\
\text { Ripuarian } \\
\text { Thuringian } \\
\text { Bavarian } \\
\text { Bavarian } \\
\text { Upper German }\end{array}$ & $\begin{array}{l}\text { SW }(90: 1-245: 35) \\
\text { SW }(67: 1-246: 5) \\
\text { SW }(68: 23-246: 5) \\
\text { SW }(218: 15-246 / 5) \\
\text { SW }(233: 15-234: 5,) \\
(237: 6-238: 17) \\
\text { SW }(67: 1-248: 23) \\
\text { SW }(78: 22-246: 9) \\
\text { SW }(67: 1-248: 23) \\
\text { SW }(67: 1-248: 23) \\
\text { SW }(134: 36-247: 22)\end{array}$ & $\begin{array}{l}- \\
- \\
- \\
- \\
- \\
- \\
- \\
- \\
- \\
-\end{array}$ & $\begin{array}{l}\text { paper } \\
\text { paper } \\
\text { paper } \\
\text { parchment } \\
\text { parchment } \\
\text { parchment } \\
\text { paper } \\
\text { paper } \\
\text { paper } \\
\text { paper }\end{array}$ \\
\hline B & $\begin{array}{r}13 \\
14 \\
141 \\
15 \\
16 \\
161 \\
17\end{array}$ & $\begin{array}{l}\text { 14th cent. } \\
\text { 15th cent. } \\
\text { 15th cent. } \\
\text { 15th cent. } \\
\text { 13th cent. } \\
\text { 13th cent. } \\
\text { 13th cent. }\end{array}$ & $\begin{array}{l}\text { Low German } \\
\text { Low German } \\
\text { Low German } \\
\text { Latin } \\
\text { Low German } \\
\text { Low German } \\
\text { Low German }\end{array}$ & $\begin{array}{l}\text { SW (113:13-117:20) } \\
\text { SW (67:1-251:16) } \\
\text { SW (90:1-159:32) } \\
\text { SW (67:1-251:16) } \\
\text { SW (67:1-258:24) } \\
\text { SW (76:11-77:8) } \\
\text { SW (67:1-248:8) }\end{array}$ & $\begin{array}{l}- \\
- \\
- \\
- \\
- \\
-\end{array}$ & $\begin{array}{l}\text { parchment } \\
\text { paper } \\
\text { paper } \\
\text { paper } \\
\text { parchment } \\
\text { parchment } \\
\text { parchment }\end{array}$ \\
\hline $\mathrm{C}$ & $\begin{array}{l}20 \\
21 \\
22 \\
23 \\
24\end{array}$ & $\begin{array}{l}\text { 15th cent. } \\
\text { 15th cent. } \\
\text { 14th cent. } \\
\text { 14th cent. } \\
\text { 15th cent. } \\
\text { 16th cent. } \\
\text { 13th cent. }\end{array}$ & $\begin{array}{l}\text { Middle/Low } \\
\text { German } \\
\text { Middle/Low } \\
\text { German } \\
\text { Low German } \\
\text { Middle/Low } \\
\text { German } \\
\text { Low German } \\
\text { Low German } \\
\text { Low German }\end{array}$ & $\begin{array}{l}\text { SW (67:1-258:24) } \\
\text { SW (67:1-258:24) } \\
\text { SW (67:1-276:20/36) } \\
\text { SW (67:1-258:24) } \\
\text { SW (67:1-258:24) } \\
\text { SW (67:1-258:24) } \\
\text { SW (67:1-258:13) }\end{array}$ & $\begin{array}{l}- \\
- \\
- \\
- \\
-\end{array}$ & $\begin{array}{l}\text { paper } \\
\text { parchment } \\
\text { parchment } \\
\text { paper } \\
\text { paper } \\
\text { parchment }\end{array}$ \\
\hline
\end{tabular}


TABLE 2

STEMMA FOR RECENSION A (1-2) (After Herkommer (1972:245-66)

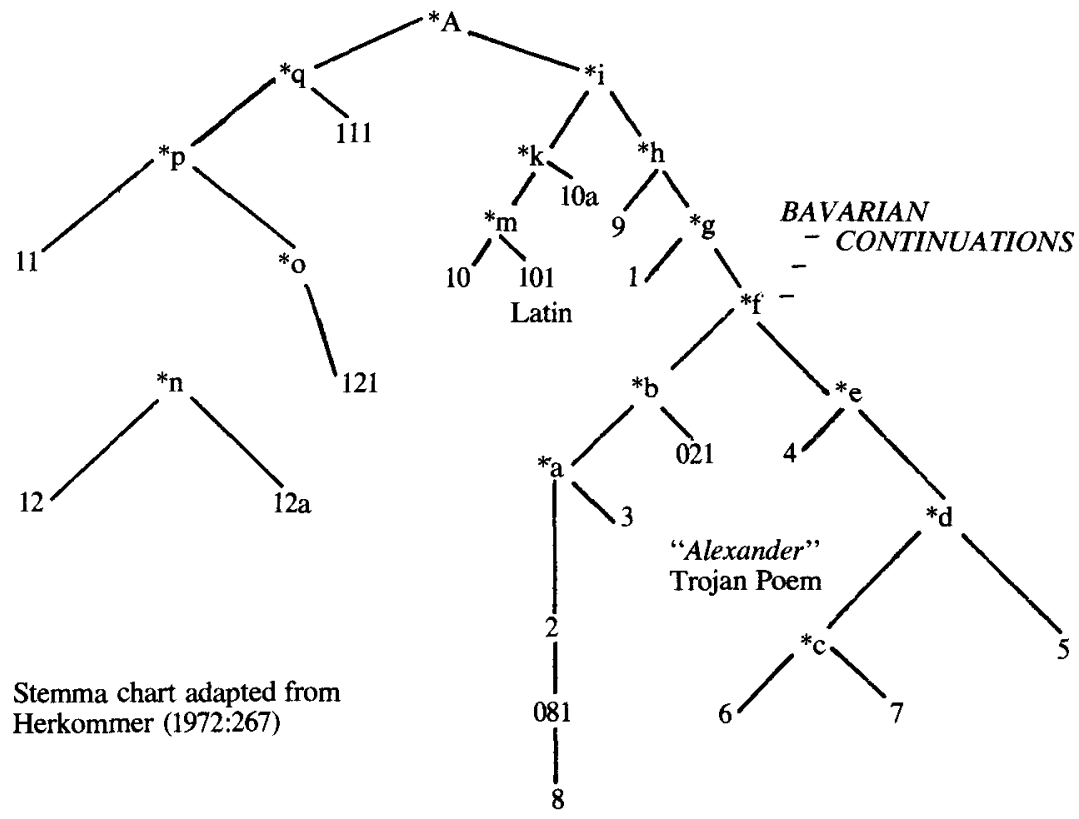


TABLE 3

\section{CONCISE DESCRIPTION OF MANUSCRIPTS}

Parenthetic letters refer to MSS $(=1-081)$ in variorum apparatus.

A-1 (A) Wolfenbüttel, Herzog-August-Bibliothek, Cod. Guelf. 23.8 Aug. $4^{\circ}$. 14th century, but before 1424 , textualis gothica, collective codex 83 leaves, $S W=1 r-83 r$. Herkommer (1972:39-41).

A-2 (B) Munich, Bayerische Staatsbibliothek, Cgm 55. 14th century, unique codex 74 leaves, $S W=1 r-66 v$. Ex Bibliotheca Sereniss. Herkommer (1972:41-2).

A-021 Basel, Öffentliche Bibliothek der Universität, Cod. E. VI. 26. 1400-39, collective codex 231 leaves, $\mathrm{SW}=17 \mathrm{vb}-156 \mathrm{vb}$. Herkommer $(1972: 42-6)$.

A-3 (C) Vienna, Österreichische Nationalbibliothek, Cod. 2692. 15th century, unique codex 84 leaves, $\mathrm{SW}=1 \mathrm{r}-72 \mathrm{r}$. MS. Ambras 262. Herkommer (1972:46-9).

A-4 (D) Heidelberg, Universitätsbibliothek, Cod. Pal. germ. 525. 15th century, before $1455 / 6$, collective codex 326 leaves, $S W=1 r-93 v$ with 1 st portion of $S W$ lacking. Bibliotheca Palatina. Herkommer (1972:49-51).

A-5 (E) Frankfurt, Stadt- und Universitätsbibliothek, Ms. germ. quart 11. 15th century, before 1452/3, collective codex 262 leaves, $S W=167 \mathrm{ra}-251$ va. Herkommer (1972:51-4).

A-6 (F) Munich, Bayerische Staatsbibliothek, Cgm 327. 15th century, 1400-30, collective codex 168 leaves, SW $=80 \mathrm{ra}-144 \mathrm{va}$. Benediktbeuren. Herkommer (1972:55-7).

A-7 (G) Nuremberg, Germanisches Nationalmuseum, Cod. 2733. 15th century, unique codex 93 leaves, $\mathrm{SW}=1 \mathrm{r}-86 \mathrm{r}$. Herkommer (1972:57-8.).

A-8 (H) Munich, Bayerische Staatsbibliothek, Cgm 3959. 15th century, before 1471, copy of 081 , collective codex 339 leaves, $\mathrm{SW}=1 \mathrm{ra}-13 \mathrm{rb}$. St. Emmeram. Herkommer (1972:58).

A-081 (I) Munich, Bayerische Staatsbibliothek, Cgm 6240. 15th century, before 1471, collective codex 290 leaves, $\mathrm{SW}=2$ ra-13ra. St. Emmeram (?). Herkommer (1972:59-65). 


\section{SOURCE OUTLINE}

The following is a diagrammatic display, chapter by chapter, according to Weiland's (1876) edition of the $S W$ showing the sources for the $S W$ as alleged by Weiland (1876), 20-33. The outline below does not indicate sections in which the Frutolf Chronicle (in Ekkehard von Aura's redaction, 1125), or the Annales Palidenses are alleged to have been employed, nor does it indicate those passages in which usage of the Stader Chronicle is considered by Weiland himself as highly speculative, nor any passages in which the Magdeburger Gesta, now lost (if ever extant in complete form), but to which reference is made in the Magdeburger Schöffenchronik and the Lauterberger Chronik, was considered by Weiland to have been employed.

\section{ABBREVIATIONS}

Acta Sil. $\quad=$ Acta St. Silvestri (c. 800) (Trierer Silvester). Der Trierer Silvester, ed. Carl Kraus (Monumenta Germaniae historica, Deutsche Chroniken I:2) (Hannover, 1895), 1-61.

Acta S.J.Q. = Acta St. Judas-Quiriaeus.

Aldhelmus $\quad=$ Aldhelmus (Althelm) (c. 640-709), De laude virginium sive de virginitate sanctorum (c. 705), ed. Rudolf Ehwald (Monumenta Germaniae historica, Auctores antiquissimi, XV) (Berlin, 1919), 226-323, $350-471$.

Beda $\quad=$ The Venerable Bede, Historia ecclesiastica Anglorum (731), ed C. Plummer, Venerabilis Baedae opera historica (London, 1896).

Chr. Mich. Lumb. = Chronicon Sancti Michaelis Luneburgensis 937-1229, ed. Ludwig Weiland (Monumenta Germaniae historica, Scriptores, XXIII), 391-397.

Decretum $\quad=$ St. Felice, Decretum Gratiani (c. 1140), Corpus Iuris Canonici. Editio Lipsiensis secunda post AEMILII LUDOUICI RICHTER. Pars I. Decretum Magistri Gratiani (Leipzig, 1879).

Eus. E.H.

$=$ Eusebius of Caesaria (c. 260-c. 340), Historia ecclesiastica, trans. Rufinus (c. 340-410), Die lateinische Übersetzung des Rufinus, ed. Theodor Mommsen. 1. Teil: Die Bücher I-V. 2. Teil: Die Bücher $V I-X$. Über die Märtyrer in Palästina (Die griechische Schriftsteller der ersten drei Jahrhunderte. Eusebius. 2. Bd.) (Leipzig, 1903-1908).

Gilbert

$=$ Gilbert, Chronicon pontificum et imperatorum Romanorum.

Helmold

$=$ Helmold von Bosau, Chronica Slavorum (c. 1150), ed. Bernard Schmeidler (Monumenta Germaniae historica, Scriptores rerum Germanicarum in usum scholarum, XXXII) (Hannover, 1937).

Hist. Dami. $\quad=$ Oliver von Paderborn, Historia Damiatina.

Hist. Sch. $\quad=$ Petrus Comestor, Historia Scholastica (c. 1170), ed. J. P. Migne (Patrologia Latina, 198), cols. 1053-1722.

Honorius $\quad=$ Honorius of Autun, De imagine mundi libri tres, ed. J. P. Migne (Patrologia Latina, 172), cols. 115-188.

Joseph-Heg. = Flavius Josephus (Hegesippus), De bello Judaico et excidio urbis Hierosolymitanae, ed. C. F. Weber and J. Caesar (London, 1864). 
Kaiserchr.

Lact. De Per. = L. Caelius Firminaus Lactantius (c. 260-c. 340), De persecutoribus, Opera Omnia, ed. Samuel Brandt (Corpus Scriptorum Ecclesiasticorum Latinorum, 19) (Prague-Vienna-Leipzig, 1890).

Leg. Aur.

Magd. Annal. = Annales Magdeburgenses, ed. G. H. Pertz (Monumenta Germaniae historica, Scriptores, XVI) (Hannover, 1859), 107-96.

Orosius

$=$ Paulus Orosius (fl. c. 417), Historiarum adversus paganos libri VII, ed. Carolus Zangemeister (Corpus Scriptorum Ecclesiasticorum Latinorum, 5) (Vienna, 1882).

P.D. Hist. Rom. = Paulus Diaconus (c. 720 c. 780), Historia romana (766-771), ed. H. Doysen (Monumenta Germaniae historica, Auctores antiquissimi, II) (Hannover, 1879).

SP

= Sachsenspiegel (c. 1220-1230), Landrecht, ed. K. A. Eckhardt (Germanenrechte N.F.) (Göttingen, 1955), Lehnrecht, ed. K. A. Eckhardt (Germanenrechte N.F.) (Göttingen, 1956).

Stad. Annal. = Annales Stadenses, ed. J. M. Lappenberg (Monumenta Germaniae historica, Scriptores, XVI), pp. 283-378.

Stad. Chr.

$=$ Albert von Stade, Weltchronik, lost, known only through citations in other sources, e.g. Thietmar von Merseburg, Chronicon, ed. Robert Holtzmann (Monumenta Germaniae historica, Scriptores rerum Germanicarum. Nova Series, IX) (Berlin, 1935).

St. Greg. De Viris = De viris illustribus (392), St. Jerome.

St. Greg. Dial. = Dialogues of St. Gregory (c. 540-604).

St. Greg. Homil. = Homilies of St. Gregory (c. 540-604).

Vulg. Com. $\quad=$ St. Jerome (c. 347-c. 420), Vulgate Bible.

\begin{tabular}{lll}
\hline SW chapter & SOURCE & UNIQUE IN RECENSION \\
\hline c. 1 & St. Greg. Homil. & \\
& Honorius \\
& Beda ? & \\
Stad. Chr. & \\
c. 2 & Honorius & \\
c. 3 & Vulg. Com. & C \\
Hist. Sch. & C \\
c. 4 & Stad. Chr. & \\
Beda (?) & \\
c. 5 & Orosius & \\
Honorius & \\
c. 6 & Beda ? & \\
Honorius ? & Stad. Chr. \\
c. 7 & Stad. Annal. & \\
Honorius &
\end{tabular}




$\begin{array}{ll}\text { c. } 9 & \text { Beda (?) } \\ & \text { Honorius (?) } \\ \text { Ctad. Chr. } \\ \text { c. } 12 & \text { Beda (?) } \\ & \text { Honorius (?) } \\ \text { c. } 13 & \text { Stad. Chr. } \\ & \text { SP }\end{array}$

c. 14

c. 15

c. 16

c. 17

c. 18

c. 19

c. 22

c. 25

c. 26

c. 30

c. 31

c. 35

c. 36

c. 37

c. 40

c. 41

c. 43

c. 44

c. 45

c. 46

c. 47

c. 49

c. 50

c. 56

c. 74

c. 75

c. 76

c. 77

c. 78

c. 79

c. 80

c. 81

c. 82

c. 83

c. 84

c. 85
Stad. Annal.

Stad. Chr.

Orosius

Beda (?)

Honorius (?)

Stad. Chr.

Kaiserchr.

Orosius

P.D. Hist. Rom.

Beda (?)

Honorius (?)

Stad. Chr.

Orosius

Kaiserchr.

Chr. Mich. Lunb.

P.D. Hist. Rom.

Honorius

Orosius

Kaiserchr.

Kaiserchr.

Stad. Chr.

Honorius

Kaiserchr.

Joseph-Heg.

Joseph-Heg.

P.D. Hist. Rom.

Kaiserchr.

Joseph-Heg.

Kaiserchr.

P.D. Hist. Rom.

Stad. Chr.

Gilbert

Magd. Annal.

Kaiserchr.

Lact. De Per.

St. Greg. De Viris

Eus. E.H.

Gilbert

Acta Sil.

Decretum

Aldhelmus

Acta Sil.

Acta Sil.

Acta Sil.

Acta Sil.

Stad. Chr.

Gilbert

Joseph-Heg.

Acta S.J.Q.

Leg. Aur. (c. 68)

Kaiserchr.

Vulg. Com.

Hist. Sch.

Eus. E.H.
A

C

C

C

C

C

C

A

C

C

C

C

C

C

C

$\mathrm{C}$
$\mathrm{C}$
$\mathrm{C}$
$\mathrm{C}$
$\mathrm{C}$
$\mathrm{C}$
$\mathrm{C}$ 
c. 89

c. 91

c. 92

c. 103

c. 107

c. 108

c. 110

c. 111

c. 113

c. 114

c. 117

c. 119

c. 137

c. 138

c. 139

c. 157

c. 158

c. 162

c. 177

c. 237

c. 262

c. 270

c. 271

c. 272

c. 273

c. 323

c. 325

c. 335

c. 358
Kaiserchr.

Eus. E.H.

Kaiserchr.

Kaiserchr.

Kaiserchr.

St. Greg. Dial.

St. Greg. Dial.

St. Greg. Dial.

St. Greg. Homil.

Gilbert

Leg. Aur. (c. 137)

Kaiserchr.

Kaiserchr.

Kaiserchr.

Kaiserchr.

Helmold (?)

Chr. Mich. Lunb.

Stad. Chr.

Chr. Mich. Lunb.

Chr. Mich. Lunb.

Magd. Annal.

Stad. Chr.

Stad. Chr.

Magd. Annal.

Stad. Chr.

Stad. Chr.

Stad. Chr.

Gilbert

Hist. Dami. (?)
C

C

C

C

C

C

C

C

A

C

$\mathrm{AB}$

AB

AB

$\mathrm{AB}$

$\mathrm{AB}$ 
TEXT (SW 78:11-25)

9v:23zv | Babilonie. Do wart im vergeben von sin selbes lueten. Do er 10r:

1 zweu vnd zweniz drizig iar alt was.

Nach Alexanders tot vrliygten die fursten von dem lande virzehen iar vmm die herschaft, die Alezander mit grozzer erbeite erworben het. Die ze furten si so sere, daz die herschaft gar zer gieng. Die sinen

5 zeteilten sich vnd zefuren in manic lant. Von dem selben her kommen auch die Sahsen. Sit wir dirre herschaft vber mer ze ende komen sin, so sullen wir auch sagen wie romischiv rich sich erhuben.

Daz romische riche was an sinem angenge aller riche daz minnest, dar nach wart ez aller riche daz sterckest vnd wirt noch aller riche

10 da k krenkest. Daz wiset got den kunig Nabukodonosor an der sul, der houpt waz guldin, die brust silbrin, der bug erin, die fuzze vnd die bain

9v:23. B(b) abiloni $C(G) H I$, Babilonien $D$, babilonia $E$; da $D F I$, vnd do $E$; ward $C H$; sein $C D E$, seins $G$, seinen $H I$; aigen $D H I$, selbs $E G$, selbis $F$; lauten $B$, luten $E F$; da $D,|11-12|$ van SE erias nach alexandrs $F$. 10r:1. (zwai)r $B(E G)$, c)t)zway $C(D)$, XXXII $H I ;|3-4|$ drizzich $B$, dreis(s)ig $C(D) E G$; allt $D$, waz $B$. 2. allexanders $D$, alexan(n)der(z) $G(H I) ;$ töd $C$, (tod)e $B(D E G H I)$, töde $F$; vrlew(u)gten $C(F)$, vrlügten $D$, vrlaugten $E$, vrling $G$, criegten $H$, vrlegten $I$; di $E F$, diu $g$; lan(n)d $G(H)$, lant $D$, $|8-9|$ mit ein ander $E$; xiiii $B H I$, vierzehen $C E$, vierttzig $D$, vier (czig) $F(G)$. 3. vmb $B C H I$, vnd $D E F G$; din $B$, di $E F$, diu $G$, dy $H$; herschafft $C E$, $\mathrm{G}(\mathrm{g})$ raffschaft $H(I)$; ze die $B$, di $E F$, diu $G ; \mathrm{A}(\mathrm{a})$ lexander $B C(E G I)$, (A)allexander $D(F)$, allexannder $H$; grösser $C$, grozzir $F$, grasser $G$, grossen(n) $H(I)$; (A)arbait (en) $B C D E F(H)$, arbeit $G$, arbaytten $I$; erf(v)ochten $D E(F)$; hett $C$, hatte $F$. 4. di $E$, diu $G$; zerfürt(t)en $B(C) D G H I$, zustürten $E$, zurfurten $F$; sy $C$, si $E$; ser $C F G H I$; diu $B G$, di $E$; zergiench $B$, alle zergieng $D$, zu(r)gieng $E(F)$; seinen $C D E G I, \| H$. 5. zertai $(\mathrm{y})$ lten $B(C) D G H I$, zutailten $E$, zuteilten $F$; sich vnder $G$, vnnd $H$; verfuren $B C H I$, züfüren $D$, furen $E$, zurfuren $F$, zerfüren $G$; in maniger $B$, in manige (w) $(C) H I$, in manig $D E G$, in manche $F$; land $C E$; den $C H I ;|11-12|$ sind auch herkommen $H I,|12| \operatorname{chomen} B C D$, $\operatorname{kamen} E$, quamen $F$. 6. uch $B,|| E$, ouch $F, \mathrm{x} H I ; \mathrm{di}$ $E$, dy $F$; sachs(s)e(n) $B C D E F G(H) I$; sei(y)t $B(C)$, seid $D$, Seind $E G H$, sint $F$; diser $C$, $|6|$ der mär vnd $D,|6|$ nu(n) der $E I$, x (mer vnd) $F(G)$, nnn der $H$; ü(v̈)ber $C(D) H I$, enhalb mers $E$; end $C D E G$, einem ennde $H I$; chomen (sein) $B(C)$, chümen sein $D$, sein $\times 1$ kumen $E, \sin$ (sein) komen $F(G)$. 7. süll $E$, solle $F$, wo(ö)l(1) $H I$; wie sich $B C E H I$; Romisch(s) $B(C D E F G)$, das römisch $H I$; reich $B C D E G H I$; | $B C E F H I$; erhub $B C$, (erhaben hab hie hebt an das römisch Reich wie es sich) erhaben hat $(E) H I$, erhaben habe $F G$. 8. ||C; Ro(ö)misch $B(C) D E F G H I$, Romsche $F$; reich $B C D G H I$, reiche $E$, rich $F ;|4-5|$ x da $\times D$; seinem $C D E G H I$, synem $F$; anegeng $B C$, anfang, angieng $G$, an(n)gang $(H) I$; vnder allen $D$; reich $B C E G H I$, reichen $D$; minnist $B$, mynnsta $C$, minst $D E G$, mynste $F$, aller mynst vn(n)d das klainest $H(I)$. 9. ward $C G I$, was $H$; $|3-7|$ daz aller $D$; reich $B C E G$; sterchist $B C$, sterkest $F G H$, sterckist $I$; vnnd $H$; $10-11 \| B$; nach $C G, \| F$; reich $B C D E G H I$, rich noch $F$. 10. chrenchist $B C$, krenckest $D E$, krenkist $F$, krenkst $G$, das (aller) mynst vn(n)d das klain(e)st $H(I) ;|3|$ vnd das selb $E$, beweist $B C$, wyste $E$, hat $\mathrm{x}$ bewei(y)st $H(I)$; dem $C D E F G H I$; kunich $B$, chunig $C$, künig $D E G I$, konig $F$, könig $H$; säul (diu er sach in sein traum) $B$, sawl $C$, sew(u)l $D(E) I$, seule $H$; das $C G H .11$. hau(w)bt $B D F G H(I)$, hawpt $C$, haup $E$; was guldein $C D I$, gulden was $E$, waz guldyn $F$, was gulden $H$; diu brust $B G$, dew (die) pru(ü)st $C(D H I)$, di p(b)rust $E(F)$; silberin $B H I$, silbrein $C D E F$, silbrin $G$; pauch $B C D E H I$, buch $F G$; erein $B D E I$, eirin $C$, eryn $F$, eren $H$; füzz $C D E G H I$; diu (die) pain $B(D E) G$, die pein $C$, di beyn $F$, $\mid$ pain $H I$. 